\title{
Instrument for Interreligious Harmony Approach in the City of Medan
}

\author{
Suardin Gaurifa \\ \{suardingaurifa@sttpk-medan.ac.id\} \\ Sekolah Tinggi Teologi Pelita Kebenaran, Medan, Indonesia
}

\begin{abstract}
The issue of harmony between religious groups is an major priority for which effective solutions must be discovered in the context of the united Republic of Indonesia. This need is particularly arises due to the increasing number of cases involving interreligious groups that have plagued people's lives in the beloved country of Indonesia. Intolerant actions that have taken place in various regions of Indonesia brought a deep concern regarding the situation which very likely can lead to deterioration of relations between people from various backgrounds of beliefs. Several issues have triggered conflict between religious communities, pertaining religious terminology, exercising offensive approach of apologetics, the neglect of the divine strategy in the restoration of the Tabernacle of David to reach out to people outside God, and the communication of evangelical inelegant terms by Christian evangelists. Therefore a comprehensive study is needed to find potential aspects to develop trust by bridging the diversities in Indonesia to ensure a harmonious social life free from intolerance and radicalism.
\end{abstract}

Keywords: Harmony, religious communities, tolerance

\section{Introduction}

The diversity of religions and beliefs is a feature that consequently produces various forms of the practice of faith.

Each religion has its unique characteristics in building spiritual life. These differences cover the manner of worship, liturgical patterns, theological concepts and perhaps most powerfully is the use of terminology as an approach to the sacred texts fundamental in each religion. Hence, religions and scriptures are inseparable. [1]

Curiosity towards another religion also is a potential source of conflict in the socio-religious context of Indonesia, particularly in the city of Medan. The advancement of social media rapidly increases this problematic matter. Tendentious questions not intended to deepen understanding other beliefs dominate the dialogue space in social media. Not rarely, abusive terminologies are expressed against the beliefs of others. Factually, according to research by The Indonesian Institute of Sciences (LIPI), social media have a major effect in encouraging acts of intolerance.

[2] Futhermore, traditional apologetic approaches of finding and exploiting weaknesses of the tenets of religious beliefs is a serious problem that exacerbates disharmony among religious communities. Various weak spots are often launched in relation to religious leaders, the authority of scriptures, even matters of tradition and its relationship with food have become topics often launched to bringing down the authority of other beliefs.

Another trigger for conflict is the inelegant delivery of the divinity of Christ by certain evangelistic groups. One practice that is not elegant is doing evangelism by proving the tenets of the Christian faith by taking evidence from other religious books and not relying on the scripture which the belief is based upon. Whereas religious history tells us that each religion has a different history of the sacred books, a different language of the book and a different 
method of interpretation. So it becomes a problem when proving what is believed based on books that are believed by other religions.

Based on that, one of the issues that has developed in Indonesia lately is the matter of blasphemy which arises due to the Law Number 1/PNPS year 1965, concerning Prevention of abuse and/or Blasphemy of Religion which states: "Everyone is deliberately prohibited in public to tell, advocate or seek public support, to make an interpretation of a religion that is held in Indonesia or carry out religious activities that resemble the religious activities of that religion, interpretation and activities which deviate from the main points of the religious teachings." Often this law is misused by certain people in trapping other religious communities.

Therefore the issue of harmony between religious groups is an major priority for which effective solutions must be discovered in the context of the united Republic of Indonesia. This need is particularly arises due to the increasing number of cases involving interreligious groups that have plagued people's lives in the beloved country of Indonesia. Intolerant actions that have taken place in various regions of Indonesia brought a deep concern regarding the situation which very likely can lead to deterioration of relations between people from various backgrounds of beliefs. Several issues have triggered conflict between religious communities, pertaining religious terminology, exercising offensive approach of apologetics, the neglect of the divine strategy in the restoration of the Tabernacle of David to reach out to people outside God, and the communication of evangelical inelegant terms by Christian evangelists.

\section{Research Method}

The method used in this study is survey and a path analysis approach. This study examines the relationship between research variables, and measures the effect of one variable on another. The data collection technique used in this study was field survey by distributing questionnaires to the congregation as the research samples. This technique is used to obtain primary data, i.e. data obtained directly from respondents. Through the statement items in the questionnaire, the congregation gave an assessment of various circumstances regarding the efforts to build harmony in the religious community in the church. This research questionnaire consisted of statements for the variables of Semitic language approach, Apologetics, restoration of the Tabernacle of David, Contextualization of the term evangelism and Religious Harmony.

Below are the items of instrument of harmony between religions 
Table 1. Kisi-kisi Instrumen Kerukunan antar umat beragama

\begin{tabular}{|c|l|c|l|}
\hline Number & \multicolumn{1}{|c|}{ Indicator } & Total & \multicolumn{1}{c|}{ Item } \\
\hline 1. & Pancasila as the foundation of the state & 4 & $1,2,3,4$ \\
\hline 2. & Unity in Diversity's motto & 4 & $5,6,7,8$ \\
\hline 3. & Principle of the blessing of harmony & 4 & $9,10,11,12$ \\
\hline 4. & Application of God's Commandments & 4 & $13,14,15,16$ \\
\hline 5. & Living in peace with others & 4 & $17,18,19,20$ \\
\hline 6 & Loving the enemy & 4 & $21,22,23,24$ \\
\hline 7 & Holistic Services & 4 & $25,26,27,28$ \\
\hline 8 & Tolerance between religions & 4 & $29,30,31,32$ \\
\hline 9 & Dialogue between religions & 4 & $37,38,39,40$ \\
\hline 10 & Positive Apologetics & & \\
\hline Total & & $33,34,35,36$ \\
\hline
\end{tabular}

\section{Discussions}

The word "harmonious" is based on the word harmony which according to Webster Dictionary is defined as adapted to each other; having a part propotioned to each other/symetrycal. This word is used in describing harmony in the music world, which sounds pleasant to hear. Also used to describe the peace of relationships between people, friends, family and society. The word harmonious in the KBBI (Indonesian Unabridged Dictionary) means (1) good and peaceful, not fighting in friendship (2) united, agreed. Meanwhile harmony means: (1) about harmony (2) harmony; agreement. [3] In the Bible harmony between people must be woven on the basis of love. The command to love humans in the second law is the same

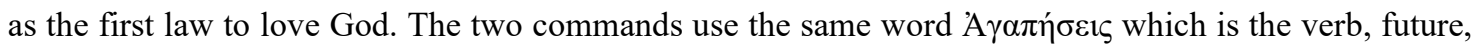
active, indicative, the second person stumps from the word $\alpha \gamma \alpha \pi \alpha \omega$ to love, have affection for-1. of persons: God J 3:16, Jesus Mk 10:21, and people 2 Cor 12:15 love, cherish, show the greatest solitude for, of the finest and most typical Christian virtues (more frequent and typically Christian than $\varphi 1 \lambda \varepsilon \dot{\omega} \omega$ but prob equivalent to it in $\mathrm{J} 21: 15-17$ ). Prove or show love (for) $\mathrm{J} 13: 1 ; 1 \mathrm{~J} 3: 18$. - 2. of the love for things love, long for, value, hold in high esteem Lk 11:43; J 12:43; 2 Ti 4: 8. [4]

Loving God leads someone to love themselves as a unique creation and then that love radiates to others. The natural continuation of loving oneself is caring for others. It is our nature as human beings to interact with others. Naturally we are not people who like to be independent. We help each other, support 
each other and care for each other. [5] Love felt in oneself will bring love to others, so harmony will manifest. So the standard, size and mirror are self. Not only by His example but also through His special teaching, Jesus clearly said that humans were never meant to live individually without caring for people outside themselves. He fully supports the Old Testament view of solidarity among human beings. [6]

\subsection{Religious Tolerance}

In the KBBI (Indonesian Unabridged Dictionary), tolerant means: being or being tolerant (respecting, allowing, allowing) the establishment (opinions, views, beliefs, habits, behavior, etc.), which is different or contrary to his position. Meanwhile tolerance means: 1) the nature or attitude of tolerance: 2) the measurement limit for the addition or reduction that is still allowed; 3) deviations that are still acceptable in work measurements. [3]

Everyone should be able to be tolerant towards others both about their culture and beliefs, but in reality that the majority always wants to win. Feel right and others are wrong, will hurt others. Even in a disadvantaged condition, believers should continue to be tolerant of other people's conditions. It seems like it would be impossible to have a harmony, if there is no mutual respect in it.

\subsection{Dialogue between religious people}

The variety of diversity in this country does not mean that harmony cannot be realized. It is precisely in this diversity that a variety of brilliant ideas will be collected when each is willing to sit together for dialogue. We should have a porch of faith for others. It is said that our house of faith should be open to other parties, although there must be an internal part that must be closed and reserved. That in dialogue with other parties, there must remain a part that is not touched and contested by other parties, namely Áqidah/dogma/doctrine of our faith, but believers should openly accept dialogue with other believers. [7]

\subsection{Research result}

Table 2. Summary of Results of Proportional Effect of Semitic language approaches (X1), Restoration of the Tabernacle of David (X2), Apologetics (X3), and Contextualization of the communication of the Gospel (X4) towards Harmony among religions (Y)

\begin{tabular}{|c|c|c|c|c|c|c|c|c|}
\hline \multirow{3}{*}{ Var } & \multicolumn{5}{|c|}{ Effect } & \multirow{3}{*}{$\begin{array}{l}\text { Total } \\
\text { Effect }\end{array}$} & \multirow{2}{*}{\multicolumn{2}{|c|}{ Outside path }} \\
\hline & \multirow{2}{*}{ Direct } & \multicolumn{4}{|c|}{ Indirect } & & & \\
\hline & & $X_{1}$ & $x_{2}$ & $x_{3}$ & $X_{4}$ & & $\mathrm{~S}$ & U \\
\hline$X_{1}$ & 0,900 & - & - & 0,0006 & - & 0,9006 & - & - \\
\hline$x_{2}$ & 0,118 & - & - & - & 0,218 & 0,336 & - & - \\
\hline$x_{3}$ & 0,021 & - & - & - & - & 0,021 & - & - \\
\hline$X_{4}$ & $-0,045$ & - & - & - & - & 0,045 & - & - \\
\hline
\end{tabular}




\begin{tabular}{|c|c|c|c|}
\hline Total & 0,6306 & & \\
\hline
\end{tabular}

\section{Conclusion}

The Semitic language approach has a direct positive effect on harmony between religions. This means that if the Semitic language approach improves, the harmony between religious communities will increase. This was obtained based on testing the hypothesis with a large path coefficient $\rho 41=0.900$ and $t=41.134$ with a significance level of 0.001 (the hypothesis is accepted if the significance level of t-count $<0.05$ ). Furthermore, based on the results as shown in table 2, the total direct effect of the Semitic language approach on religious harmony is 0.900 . This shows that $90 \%$ of changes in harmony between religions can be determined by a Semitic language approach.

An effective approach instrument for building adaptive interfaith harmony implemented in the city of Medan is built on the associative causal relationship between the exogenous variables of the Semitic language approach and the restoration of the Tabernacle of David. The model of building inter-religious harmony which is a research finding explains that it can be done through strengthening the Semitic language approach and the restoration of the Tabernacle of David. The better the approach of Semitic language, the better the harmony between religious communities will be better. Furthermore the application of the restoration of the Tabernacle of David is improves, the harmony between religions will increase. Models The findings of the research can be described in the following chart.

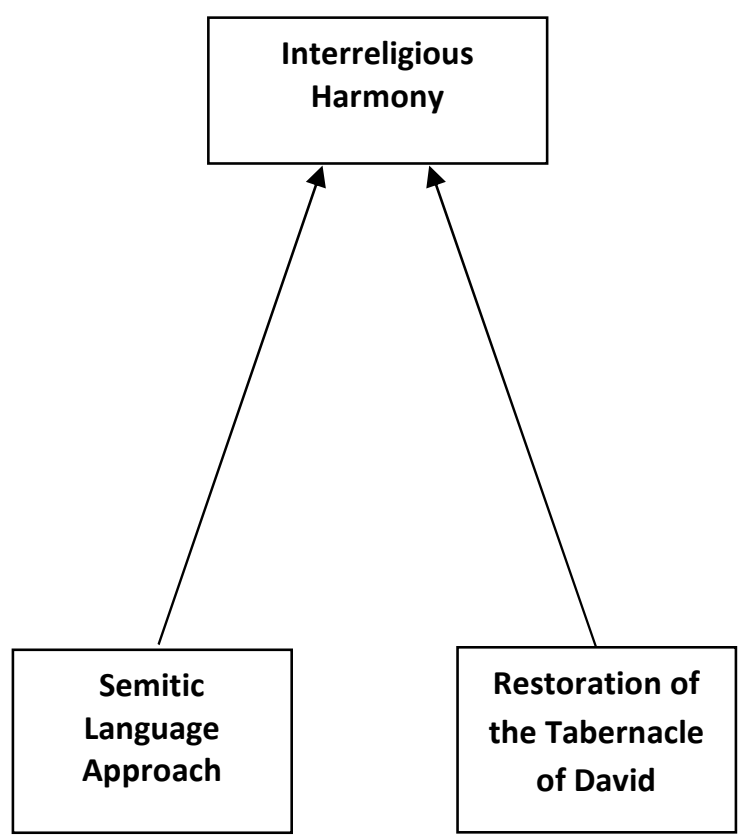

References 
[1] I. Sastrawat, "No Title," kompasiana, 2015. [Online]. Available: https://www.kompasiana.com/islamrasional79.blogspot.com/550dd618a33311ae2dba7d2a/mengenalagama-dan-bahasa-kitab-suci-dunia?page=all. [Accessed: 03-Nov-2019].

[2] N. Nasrullah, "No Title," Republica.co.id, 2018. [Online]. Available: https://www.republika.co.id/berita/dunia-islam/islam-nusantara/18/12/05/pj8toz320-peneliti-lipi-ungkapkorelasi-media-sosial-dan-intoleransi. [Accessed: 05-Nov-2019].

[3] T. Penyusun, "Kamus Besar Bahasa Indonesia," Jakarta: Balai Pustaka, 1999, p. 757.

[4] "Biblework.".

[5] W. A. Miller, Puas, Lega dan Bahagia. Bandung: Kalam Hidup, 1996.

[6] D. Guthrie, Teologia Perjanjian Baru Jilid I. Jakarta: BPK Gunung Mulia, 1993.

[7] B. Daghi, Diutus untuk berdialog dalam buku Allah Akbar Allah Akrab. Maumere: Ledalero, 2003. 